\title{
TRUTH DAN POST TRUTH DALAM PERSPEKTIF AL-KINDI PADA ERA MILENIAL (MEDIA SOSIAL)
}

\author{
Cika Anugrah Septiyadi', Zahrotul Khafifah ${ }^{2}$, Adesilvi Saisatul Khumairoh ${ }^{3}$, \\ Achmad Fauzan Hidayatullah ${ }^{4}$ \\ 1,2,3,4Fakultas Sains dan Teknologi, Universitas Islam Negeri Walisongo,Indonesia
}

\section{DOI: 10.23917/humaniora.v22i1.9344}

Submit: 25 November 2019. Revisi: 12 Januari 2021. Diterima: 18 January 2021. Available Online: 27 Januari 2021. Periode Terbit: Februari 2021.

\begin{tabular}{l}
\hline Keywords \\
\hline ethics, \\
hoax, \\
human, \\
internet \\
\\
\hline Corresponding \\
Author \\
\hline Cika Anugrah Sep- \\
tiyadi \\
Universitas Islam \\
Negeri Walisongo \\
Indonesia \\
Email: \\
yadi_20_1808086010 \\
@student.walisongo. \\
ac.id \\
Telp: \\
+6282235792322
\end{tabular} Abstract
People have desires to search for the truth and to have broad knowledge. The internet, which was once considered as one of the media to find accurate sources of information, now has become a source of less accurate news. So there needs to be a filter in consuming news from the internet. The purpose of this study is to look at the spread of hoax news because of the lack of awareness. The majority of social media users in the current era do not have an ethical foundation in using their right to express their opinions properly which result in hoaxes. We use literature review method to collect all the information required. In the end, we conclude that people must give an opinion by thinking about the truth first of what they have conveyed. From the truth, it can be understood that something must be justified. In accordance with the truth meant by Al-kindi that in seeking truth must to find the main source of the source itself.

$+6282235792322$

\begin{tabular}{ll}
\hline Kata Kunci & Abstrak \\
\hline etika, & Umumnya manusia memiliki keinginan untuk mencari kebenaran dan \\
hoax, & memiliki pengetahuan yang luas. Internet yang dulunya dianggap se- \\
internet, & bagai salah satu media untuk mencari sumber informasi yang akurat, \\
manusia & kini menjadi sumber berita yang kurang akurat. Perlu adanya filter da- \\
& lam mengonsumsi berita yang ada di internet. Tujuan dari penelitian \\
& ini adalah untuk membendung penyebaran berita Hoax karena masih \\
& minimnya kesadaran masyarakat di era saat ini, mayoritas pengguna \\
& media sosial di era saat ini belum memiliki landasan etis dalam \\
& menggunakan haknya untuk mengutarakan pendapatnya. sehingga me- \\
& nyebabkan pendapat memikirkan kebenaran terlebih dahulu tentang \\
& apa yang telah dia sampaikan. Dari kebenaran dapat dipahami bahwa \\
& sesuatu harus dibenarkan. Sesuai dengan kebenaran yang dimak- \\
& sudkan oleh Al-Kindi bahwa dalam menemukan kebenaran harus \\
& menemukan sumber utama dari sumber tersebut.
\end{tabular}

\section{PENDAHULUAN}

Salah satu bentuk pergeseran yang terjadi sekarang adalah media sosial menjadi sumber dominan dan paling penting dari informasi bagi masyarakat Indonesia. Bahkan media sosial juga menjadi sumber utama untuk informasi 
agama dan pengetahuan. Pengaruhnya pun semakin terlihat. Berdasarkan penelitian Efendi, dkk. (2017) media baru (digital) mampu mempengaruhi perilaku, dikatakan bahwa semakin tinggi interaksi anak dengan media baru (digital) cenderung semakin rendah interaksi sosial mereka. Nisrina, dkk(2020) menyatakan platform media dengan dukungan akses internet yg mudah membuat arus globalisasi semakin pesat dan membuat budaya asing masuk dengan mudah. Masyarakat modern bergantung pada sumber informasi, terutama dari lini masa Facebook mereka, meeskipun tidak semua informasi mengandung kebenaran.

Berbagai penelitian telah menunjukkan bahwa media sosial telah menjadi platform untuk menyebarkan berita palsu. Banyak saluran berita yang dibentuk oleh kelompok-kelompok ideologi politik membingkai semua berita berdasarkan kepentingan ideologis mereka (Alimi, 2019). Alih-alih media sosial menjadi ruang publik untuk menciptakan partisipasi politik yang positif. Media sosial yang negatif memengaruhi debat publik, seperti menyebarkan berita palsu dan menciptakan "ruang gema".

Media sosial juga telah menciptakan Hoax dan membagi masyarakat menjadi berkelompok- kelompok (Borden, 2007). Media sosial telah menjadi ruang gema, bukan ruang publik yang memelihara democracy. Echo ruang adalah ruang gema yang berisi pandangan orang yang berpikir sama dan satu rasa agar tidak menghasilkan dialog yang baik. Ruang gema melembagakan pandangan satu sama lain sehingga mereka menjadi terasing satu sama lain. Harapan semestinya adalah internet dapat menjadi "ruang publik", yaitu suatu daerah dalam kehidupan sosial di mana individu dapat dengan bebas mendiskusikan dan mengidentifikasi masalah sosial, dan melalui diskusi ini memengaruhi tindakan politik (Habermas, 1991: Alimi,2019).

Jenis-jenis Informasi Hoax:

1. Fake news:

Berita bohong: Berita yang di dalamnya berusaha untuk menggantikan berita yang sebenarnya untuk kepentingan pihak-pihak tertentu

2. Clickbait:

Tautan jebakan: Tautan yang diletakkan secara stategis di dalam suatu situs untuk menarik minat pembaca, tautan ini berisi hal yang benar, tetapi tautan ini diberi judul yang dilebih-lebihkan.

3. Confirmation bias : Bias konfirmasi:

Kecenderungan untuk memberikan bukti yang sebaik-baiknya sehingga mendukung pendapatdan menolak apabila terdapat bukti yang sebaliknya

4. Miss information:

Informasi yang tidak valid dan digunakan untuk menipu

5. Satire:

Sebuah tulisan yang dibesar-besarkan untuk mengkomentari kejadian yang sedang hangat. 


\section{Post-truth:}

Pasca-kebenaran: Kejadian di mana emosi lebih berperan daripada fakta untuk membentuk opini publik.

\section{Propaganda:}

Aktivitas menyebarluaskan berita dan informasi yang akan memengaruhi pemikiran publik (Rahadi 2017).

Dalam ruang gema media sosial atau media cetak, kita mungkin akan seperti prihatin dengan (era kebenaran) seakan-akan kita memiliki kekuatan untuk perhatian langsung seperti kita prihatin dengan berita palsu. Sebagian besar orang banyak memilih kebenaran yang dapat dianggap menonjol dan penting yang mereka klaim itu dapat dianggap benar dan salah dan pilihan ini memiliki konsekuensi penting (Atlantic, 2017)

Harry G. Frankfurt menulis journal Raritan Quarterly Review (1986) tiga puluh dua tahun lalu. Frankfurt menyampaikan bahwa salah satu ciri yang paling menonjol membangun struktur dari budaya kita adalah bahwa ada begitu banyak omong kosong, begitu banyak hoax dan berita palsu. Akan tetapi, kebanyakan dari kita cenderung menganggap situasi seperti biasa. Kebanyakan orang juga percaya diri dalam kemampuan mereka untuk mengenali omong kosong serta hoax dan mereka berpikir tidak mungkin bagi mereka untuk diakali dengan hoax.

Kebanyakan orang berpikir bahwa mereka tidak akan tertipu oleh Hoax dan omong kosong. Oleh karena itu, fenomena ini tidak menyebabkan perhatian serius atau yang menyebabkan berlangsung penyelidikan mengenai kebenaran. Berita hoax cenderung diterima apa adanya (diterima begitu saja). Jadi, kita tidak memiliki pemahaman yang jelas tentang apa itu omong kosong, yang memanifestasikan dirinya melalui hoax, mengapa ada begitu banyak atau apa fungsinya kita menerima. Apa artinya bagi kita (Frankfurt, 1986). Omong kosong secara luas dipahami di sini sebagai kurangnya perhatian terhadap kebenaran, kondisi yang di dalamnya emosi dianggap lebih penting daripada fakta dan bukti.

Jika era pascakebenaran dimulai dengan meledakkan struktur pengetahuan saat ini, maka sangat tidak mungkin demokratisasi, dan pada kenyataannya sebagian besar mengarah cenderung otoriter. Namun, justru dunia menunjukkan bahwa munculnya era pascakebenaran mungkin lebih mungkin daripada kebanyakan orang yang pernah bayangkan. Fakta seperti yang kita ketahui sering muculnya fakta modern, yang timbul dari konfigurasi tertentu praktik, wacana, politik, dan lembaga epistemik (Atlantic 2017).

Mengapa pada manusia modern menerima berita hoax? Di antara hal-hal yang mengejutkan adalah bahwa Hoax (omong kosong) telah menjadi bagian dari budaya kontemporer. Manusia modern bahkan tampaknya omong kosong menjadi kecanduan dan kebutuhan. Manusia modern telah demikian tergantung pada omong kosong, yang sekaligus ancaman terbesar. Jon Lo-Vett (2013) menulis bahwa salah satu ancaman terbesar yang kita hadapi adalah hanya menempatkan omong kosong. Kami tenggelam di dalamnya. Kami tenggelam dalam retorika 
partisan yang tidak dapat digambarkan sebagai sebuah kebohongan; dalam penelitian yang disponsori industri; di media sosial palsu dari hubungan manusia; dalam dua bahasa perusahaan dan hukum. Omong kosong menginfeksi setiap aspek kehidupan masyarakat, merusak wacana kami, merusak kepercayaan kami di lembaga-lembaga besar, menurunkan standar kami untuk kebenaran, dan mempersulit pencapaian sesuatu apapun (Alimi 2019).

Pada saat ini Indonesia sudah masuk dalam era globalisasi. Salah satunya ditandai dengan mudahnya masyarakat mendapatkan informasi dari berbagai belahan dunia akibat perubahan teknologi yang semakin besar (Anwari 2018). Mudahnya informasi yang didapat dari luar tanpa adanya penyaringan informasi oleh pemerintah secara masif membuat adanya dampak dari luar yang mampu mempengaruhi perilaku masyarakat, termasuk generasi milenial. Seberapa besar atau kecilnya pengaruh yang didapat tergantung pada seberapa banyak informasi yang diperoleh dan dimaknai benar dan diterima oleh masyarakat, terutama masyarakat milenial zaman sekarang yang sangat merasakan pengaruh dari dampak globalisasi ini (Siswoko 2017).

Perubahan masyarakat, termasuk generasi milenial ke arah digitalisasi menjadikan gagasan rezim post-truth semakin substansial dalam menggambarkan kehidupan. Istilah post-truth hampir tidak dikenal sekitar 5 tahun yang lalu, tetapi mulai berkembang ke panggung media baru-baru ini. Istilah post-truth sebenarnya sudah muncul sejak 2004 sebagai pengaburan batas antara berbohong dan pengungkapan kebenaran. Akan tetapi, fenomena post-truth menjadi perhatian publik sekitar November 2016 ketika Kamus Oxford menamakannya di tahun 2016. Inisiasi tersebut digagas setelah melihat lonjakan penggunaan kata posttruth yang mencapai dua ribu persen selama tahun 2015(Jatmiko, 2019).

Masuk akal, kita berada dalam era pascakebenaran bukan karena orang tidak lagi peduli tentang kebenaran, tetapi karena banyak keyakinan yang tidak responsif terhadap bukti yang benar. Mungkin ini fenomena yang timbul dari perubahan pada psikologi dari orang-orang (misalnya, lebih besar kecemasan mungkin membuat orang lebih rentan terhadap perbedaan sikap dan rentan kurangnya argumen).Mungkin juga timbul dari perubahan dalam lingkungan eksternal (misalnya, mungkin fenomena ini dijelaskan oleh penurunan nilai tradisional dan kenaikan situs berita palsu). Itulah salah satu masalah penting yang paling yang dihadapi saat ini. Semakin ada berbagai isu orang tampaknya membentuk pikiran mereka dengan cara yang berbeda dengan masing-masing bukti yang mereka punya (Levy, 2017).

Lazimnya dari hasil perkembangan teknologi, internet terutama media sosial memiliki dua sisi. Di satu sisi, kehadiran internet dipandang dapat membantu dan memudahkan terkoneksinya masyarakat. Di sisi lain internet dan media sosial memiliki dampak negatif ketika berhadapan dengan aspek etika dan moral (Fahrimal, 2018). 
Media sosial memungkinkan penggunanya untuk berinteraksi dengan khalayak umum (Rheingold 2018), media sosial digunakan dengan produktif oleh seluruh masyarakat untuk bisnis, politik, dan media periklanan. Media sosial merupakan sebuah alat yang sangat baik untuk memengaruhi seseorang mengenai isu-isu sosial di sekitar (Carr, 2015).

Landasan truth hadir untuk membantu mengatasi perilaku masyarakat, termasuk anak milenial zaman sekarang yang perilakunya jauh dari etika dan moral bermedia sosial yang diharapkan dan selalu menerima bahwa segala sesuatunya benar tanpa harus diperiksa atau dipertimbangkan terlebih dahulu. Hal itu sesuai dengan apa yang dikatakan Al-Kindi dalam filsafatnya yang menyatakan kebenaran pertama (Tuhan) adalah sebab bagi setiap kebenaran, untuk itu kita harus mencari sumber kebenaran yang sesungguhnya.

\section{METODE}

Penelitian yang digunakan dalam artikel ini yaitu metode kajian pustaka dan analisis data. Metode kajian pustaka atau metode studi literatur yang berisi tentang teori yang relevan dengan masalah-masalah penelitian (Rahmawati, et al., 2019).

Metode teknik analisis data yang digunakan ditujukan untuk menganalisis data dari berbagai sumber yang valid kemudian dibandingkan dan digabungkan dengan data-data yang ada sehingga tercipta pengertian yang relevan (Mirzaqon, 2018).

Menurut (Supriyadi, 2017), metode analisis data atau kajian pustaka merupakan metode dengan cara pengumpulan data-data dari beberapa sumber seperti buku, jurnal-jurnal,dan beberapa dokumen baik yang berbentuk cetak maupun elektronik yang berisi tentang data-data yang akan mendukung relevansi kajian atau penelitian.

Dari beberapa pengertian tersebut dapat dipahami bahwa metode analisis data atau kajian pustaka merupakan metode yang dilakukan dengan mengumpulkan, mengolah dan membandingkan data atau informasi secara sistematis sehingga didapat hasil yang relevan guna mendukung penelitian yang sedang dilakukan (Khatibah, 2011).

\section{HASIL}

Hasil penelitian menemukan enam temuan yang dapat dijabarkan dalam pembahasan. Hasil penggalian data tersebut dapat diuraikan dalam enam rincian berikut. Internet mencakup media sosial sangat rentan terhadap tidak akuratnya suatu informasi; Masyarakat Indonesia termasuk di dalamnya generasi milenial belum mampu saring informasi dengan baik dan benar sehingga memunculkan berita hoax.

Berita hoax terus bermunculan dan terus menyebar luas tanpa dapat terkendali. Akibat dari pemunculan berita hoax tersebut, muncul fenomena posttruth yang di dalamnya terdapat berita-berita palsu yang luas tanpa terkendali. 
Filsafat hadir sebagai jawaban pemecah masalah dari semua ketidakbenaran itu. Filsafat erat kaitannya dengan kebenaran dan etika, moral, dan kesusilaan setiap manusia sehingga setiap kali manusia bertindak harus terlebih dulu berfikir dan mencerna apa yang akan disampaikan dan dilakukannya sehingga akan memunculkan suatu kebenaran atau informasi yang benar.

Kebenaran Al-Kindi dapat dipakai menjadi suatu landasan kebenaran. Kebenaran dapat dimaknai beliau adalah semakin seorang manusia dekat dengan kebenaran, maka akan semakin pula manusia dekat dengan kesempurnaan dengan cara mengetahui kebenaran dan menindaklanjuti dengan suatu amal perbuatan dan tindakan.

\section{PEMBAHASAN}

Media sosial di dalamnya sering kali dijumpai hoax. Hoax adalah suatu berita kebohongan yang diperbuat oleh seseorang yang isi atau kebenarannya tidak dapat dipertanggungjawabkan. Faktor yang menyebabkan tersebarnya hoax di masyarakat umumnya disebabkan oleh pihak yang ingin mencari perhatian publik (yang dikenal sebagai pansos) yang biasanya bertujuan untuk meyudutkan suatu pihak (Septanto, 2017). Hoax juga dapat disebabkan oleh seseorang yang hanya ikutikutan agar terlihat lebih seru, yaitu dengan menyebarkan berita yang tidak diketahui kebenarannya sehingga banyak orang yang berkomentar di media sosial dan media sosial terlihat lebih ramai (Wahyono, et al., 2017). Untuk dapat mengenali berita hoax yang beredar, masyarakat perlu mendapatkan edukasi dan wawasan yang luas agar semua masyarakat dapat terhindar dari berita yang sesat atau hoax (Marwan, 2016).

Menurut (Kurniawan, 2018), media sosial menjadi ladang untuk berkembangnya post-truth dengan sangat baik dan dapat dilihat dengan secara langsung, bahkan kebenaran yang dibenarkan menjadi argumen dan didisinformasikan menjadi fakta yang parsial (Siswoko, 2017) juga mengatakan di era post- truth ini kebenaran dan berita hoax sudah menjadi sangat sulit untuk dibedakan. Post-truth dalam bahasa Indonesia sudah mencapai taraf pasca kebenaran. Berita hoax, palsu, bahkan lebih banyak dipercayai publik dibandingkan dengan berita yang sudah jelas terverifikasi di platform sosial.

Suatu kebenaran yang ada dapat menjadi kebohongan atau biasa disebut hoax, yang disebabkan oleh ulah masyarakat yang memutar-balikkan fakta yang ada hingga tidak sesuai dengan kenyataan yang sebenarnya sehingga banyak orang yang merasa dirugikan oleh peristiwa hoax ini (Marwan, 2016).

Berita mengenai kebohongan atau hoax hampir ada di seluruh penjuru dunia, termasuknya di Indonesia. Kasus hoax yang pernah viral di Indonesia yang terdapat di laman web sosial detik.com salah satunya yaitu menceritakan kasus tentang Audrey. Dalam beritanya kasus pengeroyokan terhadap Audrey yang dilakukan oleh 12 siswa pada hari Rabu, 10 April 2019 yang terjadi karena dilatarbelakangi oleh masalah asmara dan saling ejek di media sosial. Masalah 
tersebut memicu terjadinya pengeroyokan dan mengakibatkan korban (Audrey) mengalami depresi, luka fisik, sampai kemaluannya rusak.

Berita tersebut tersebar luas dengan cepat di medsos sehingga menjadikan para netizen atau publik merasa kasihan dan memicu kemarahan terhadap para pelaku pengeroyokan. Kasus ini beredar di media sosial terutama di instagram hingga mucul tagar \#justiceforAudrey karena banyak masyarakat yang simpati kepada Audrey, tak lama itu muncul tagar baru \#Audrey juga bersalah yang memiliki maksud untuk mempertanyakan kebenaran berita tentang pengeroyakan Audrey. Beberapa bulan setelah kasus itu beredar, pihak berwajib melakukan penyelidikan dan melakukan tes visum, ternyata dari tes tersebut berbanding terbalik dari kenyataan yang ada, dan si pelaku pengeroyokan ternyata tidak melakukan kekerasan terhadap Audrey sehingga kasus ini dianggap berita yang hoax dan merupakan salah satu bentuk pansos dari Audrey (Goleman, 2017).

Terbatasnya aturan yang telah ditetapkan oleh pemerintah juga menjadi salah satu faktor dalam merebaknya berita hoax di media sosial. Pemerintah mengeluarkan peraturan mengenai undang-undang ITE (informasi teknologi dan elektronik) untuk mengatasai masalah di media social. Namun, apabila undangundang tersebut tidak di indahkan oleh pengguna internet, maka hanya akan menjadi hal yang sia-sia (Fahrimal, 2018).

Fenomena post-truth atau suatu kesalahan (Hoax) yang dipercayai banyak orang sehingga menjadi suatu kebenaran, dewasa ini telah menjadi masalah yang umum di media social. Menurut (Rahadi,2017) hoax telah menjadi permasalahan yang dihadapi oleh hampir oleh seluruh negara. Penyebaran berita bohong menciptakan masyarakat menjadi terpecah belah karena memiliki pandangan yang berbeda. Dalam dunia digital manusia terkoneksi satu sama lain dalam suatu dunia yang bernama internet (Suparno, 2012). Media yang dahulunya dianggap sebagai sumber tempat mencari informasai yang terpercaya telah menjadi tempat yang diragukan kebenarannya dikarenakan tipisnya dinding pemisah antara kebenaran dan kebohongan. Kehadiran media sosial juga bisa menjadi alat untuk bebas mengekspresikan suatu pendapat di internet. Media sosial dijadikan ajang mempresentasikan diri (Wahyono, et al., 2017).

Ketika media tradisional berubah menjadi digital, banyak sekali masyarakat yang dapat mengakses media dengan bebas (free) (Alatas, 2014) sehingga penyebaran berita palsu dapat berkembang dengan pesat. Ketika berita palsu ini disebarluaskan dan dipercayai oleh masyarakat, hal inilah yang akan menjadi posttruth. Terbaginya masyarakat ke beberapa golongan akibat perbedaaan pendapat ini dapat menimbulkan bergejolaknya emosional antara penganut pendapat satu dan lainnya (Jatmiko, 2019).

Al- Kindi, Alkindus, nama lengkapnya Abu Yusuf Ya'kub ibn Ishaq ibn Sabbag ibn Imran ibn Ismail al-Ash'ats ibnn Qais al-Kindi, lahir di Kufah, Iraq, sekarang tahun $801 \mathrm{M}$, pada masa khalifah Harun Al-Rasyid (786-809) dari dinasti Bani Abbas (750-1258 M). Karena itu, dia disebut juga dengan filosof Arab. 
Sebagai filosof awal, pemikiran utamanya ialah mengenai upaya menghubungkan agama dengan filsafat yang pemikiran beliau mengacu kepada cara beretika. Pemikiran ini dituangkan dalam karyanya Fi Falsafah al-Ūlā' (Bakti, 2016).

Al-Kindi adalah tokoh penting dalam filsafat Arab. Di satu sisi, ia melihat kebenaran dari sisi belakang kepada orang-orang kuno, terutama Aristoteles. AlKindi mengatakan kebenaran dalam buku From Africa to Zen:"Kita seharusnya tidak malu untuk mengagumi kebenaran atau untuk memperoleh itu dari mana pun sumbernya. Bahkan jika kebenaran tersebut berasal dari tradisi dan bangsa asing. Hal ini penting bagi para pencari kebenaran bahwa kebenaran jauh lebih penting karena dia yang mencari kebenaran disana tidak ada yang lebih tinggi nilainya daripada kebenaran itu sendiri. Kebenaran tidak bisa direndahkan oleh orang atau suatu bangsa, begitu pula tidak ada yang direndahkan oleh kebenaran apapun derajatnya".

Dalam perspektif Al-Kindi, untuk mendapatkan sebuah kebenaran perlu adanya suatu tata cara hidup yang baik, yaitu beretika. Ketika manusia memahami kodratnya sebagai manusia, maka dia akan hidup dalam suatu kebahagiaan. Pandangan Al-Kindi mengenai filsafat adalah bahwa tujuan para filosof dalam berteori adalah mengetahui kebenaran yang kemudian ditindaklanjuti dengan suatu amal perbuatan dalam tindakan, maka semakin seorang manusia dekat pada kebenaran, maka semakin seorang manusia akan dekat pula pada kesempurnaan (Madani, 2015).

Oleh sebab itu, sangat penting dalam menyiapkan generasi milenial terhadap pengaruh globalisasi yang saat ini sedang berlangsung (Sukarman, 2019). Pentingnya dalam sekolah-sekolah ditanamkan pendidikan karakter bagi para pelajarnya, khususnya etika sehingga mampu memahami kebenarann tidak hanya dari satu sisi dan tidak mudah terpengaruh oleh dunia luar termasuk pengaruh dari media sosial (Lalo, 2018).

Berkaitan dengan hal tersebut, ancaman post-truth yang menyerang berbagai elemen kehidupan manusia tampaknya juga membutuhkan pendekatan multidisiplin yang lebih terintegrasi agar penyebaran informasi palsu (hoax) agar tidak tambah beredar luas di kalangan masyarakat. Ada beberapa hal faktor utama dalam penyebaran berita hoax, diantaranya yaitu ketika suatu platform menyediakan suatu sajian berita yang menarik untuk dijadikan berita, padahal berita tersebut belum tentu benar (Ott, 2017).

Tersebarnya berita hoax di media sosial telah mengakibatkan dampak negatif yang amat terasa bagi kehidupan manusia. Bebrapa dampak negatif yang dihasilkan diantaranya ialah merugikan masyarakat karena sebagian besar isi berita tersebut adalah fitnah dan kebohongan (Umaya, 2017), memecah belah publik, baik atas kepentingan politik atau organisasi agama tertentu. Berita hoax dapat memengaruhi opini publik; berita-berita hoax sengaja dibuat untuk mendiskreditkan salah satu pihak sehingga akan muncul adu domba (Allcott, 2017). Selain itu, menurut (Rusdiyanto, 2019), hoax adalah berita yang akan 
membuat pembacanya menjadi bingung untuk mempercayai berita tersebut. Posttruth juga bukan sekadar berita bohong belaka, namun juga berita yang diolah dengan baik sehingga hampir menyerupai kebenaran (Wahyurudhanto, 2019).

Dalam memberantas berita palsu (hoax) kontribusi pemerintah dalam menyebarkan informasi yang real sangat dibutuhkan (Golose, 2019). Selain itu, dalam mengungkap kebenaran disarankan berbagai cara yang dapat ditempuh diantaranya yaitu: pertama, membaca atau menemukan informasi dari sumber atau situs terpecaya (Sauda, 2013). Kedua, melakukan re-check terlebih dahulu jika mendapat informasi (berita) mengenai suatu hal di media sosial. Ketiga, tidak langsung menge-share suatu informasi yang belum pasti kebenarannya. Banyak sekali masyarakat yang baru mengenal sosial media menyebarluaskan berita yang mereka dapat tanpa membuktikannya terlebih dahulu agar dianggap sebagai "sang sumber informasi" dan pola ini berulang-ulang. Ketika seseorang mendapatkan informasi itu kembali, maka ia akan merasa bahwa informasi yang ia terima itu adalah yang paling akurat (Mudawamah, 2018). Keempat, mulai melakukan budaya sharing sebelum sharing, kebanyakan penggguna internet yang masih awam akan malas untuk mencari tahu kebenaran yang berasal dari internet menggunakan search engine (Lazonder, et al., 2000). Hal ini dirasa akurat karena sebagai generasi milenial, selain harus eksis, dituntut juga untuk realistis, berpikir kritis, dan rasional mengenai suatu informasi agar nantinya kebenaran dapat dibuktikan dan berita palsu (hoax) tidak semakin tersebar secara luas di kalangan masyarakat, khususnya generasi milenial (Juditha, 2018).

\section{SIMPULAN}

Hoax yang beredar saat ini disebabkan oleh ulah sekelompok orang ataupun seseorang yang berita itu tidak dapat dipertanggungjawabkan kebenarannya. Sesuai dengan kebenaran yang dimaksud oleh Al-Kindi bahwa dalam mencari kebenaran harus mencari sumber utama serta dalam mengetahui kebenaran harus ditindaklanjuti dengan amal perbuatan dan tindakan. Oleh karena itu, dalam era globalisasi ini untuk setiap manusia terutama generasi milenial, diharuskan bepikir kritis dan melakukan cross check untuk menghindari penyebar luasan hoax yang terjadi di media sosial sehingga kebenaran mengenai suatu informasi akan tecipta di tengah-tengah masyarakat Indonesia.

\section{DAFTAR PUSTAKA}

Alatas, S. (2014). "Media Baru, Partisipasi Politik dan Kualitas Demokrasi". Konferensi Nasional Komunikasi.

Alimi, M. Y. (2019). Theorizing Internet, Religion and Post truth an Article Review. https://doi.org/10.15294/komunitas.v11i2.21860

Allcott, H., \& Gentzkow, M. (2017). Social Media and Fake News in The 2016 Election. Journal of Economic Perspectives, 31(2), 211-236. https://doi.org/10.1257/jep.31.2.211

Atlantic, T. (2017). Post-truth? Social Studies of Science, Vol. 47(1). https://doi.org/10.1177/0306312717692076 
Bakti, H. (2016). "Mashsha'Iyah: Mazhab Awal Filsafat Islam". Jurnal THEOLOGIA, 27(1), 73-102. https://doi.org/10.21580/teo.2016.27.1.919

Binti Ida Umaya. (2017). Hoax dan Banatalitas Kejahatan. Universitas Nusantara PGRI Kediri, 01(32), 1-7.

Carr, C., \& Hayes, R. (2015). "Social Media: Defining, Developing, and Divining". Atlantic Journal of Communication, 23, 46-65. https://doi.org/10.1080/15456870.2015.972282.

Efendi,A., Astuti,P. I., \& Ruhayu, N.T. (2017) Analisis Pengaruh Penggunaan Media Baru terhadap Pola Interaksi Sosial Anak di Kabupaten Sukoharjo. Jurnal Penelitian Humaniora. 18(2), 12-24. DOI: https://doi.org/10.23917/humaniora.v18i2.5188

Fahrimal, Y. (2018). "Netiquette: Etika Jejaring Sosial Generasi Milenial dalam Media Sosial". Penelitian Pers dan Komunikasi Pembangunan, 22(1), 69-78.

Goleman, daniel; boyatzis, Richard; Mckee, A. (2017). "Islam Filsafat Intergovernmental Panel on Climate Change". Journal of Chemical Information and Modeling, 1(1), 1-5. https://doi.org/10.1017/CBO9781107415324.004

Golose, P. R. (2019). "Strategi Penanganan Firehose of Falsehood pada Era PostTruth". Jurnal Ilmu Kepolisian, 13(April).

Jatmiko, M. I. (2019). "Post-Truth, Media Sosial, dan Misinformasi: Pergolakan Wacana Politik Pemilihan Presiden Indonesia Tahun 2019". Jurnal Dakwah Tabligh, 20(1), 21. https://doi.org/10.24252/jdt.v20i1.9529

Juditha, C. (2018). "Hoax Communication Interactivity in Social Media and Anticipation (Interaksi Komunikasi Hoax di Media Sosial serta Antisipasinya)". Journal Pekommas, 3(1), 31. https://doi.org/10.30818/jpkm.2018.2030104

Khatibah. (2011). "Penelitian Kepustakaan". Jurnal Iqra', 5(01), 36-39. URI:http://repository.uinsu.ac.id/id/eprint.

Kurniawan, B. (2018). "Politisasi Agama di Tahun Politik : Politik Pasca-Kebenaran di Indonesia." Jurnal Sosiologi Agama -, 12(1), 133-154. DOI: https://doi.org/10.14421/jsa.2018.121-07.

Lalo, K. (2018). "Menciptakan Generasi Milenial Berkarakter dengan Pendidikan Karakter guna Menyongsong Era Globalisasi". Ilmu Kepolisian, 12(2), 6875. http://www.jurnalptik.id/index.php/JIK/article/view/23.

Lazonder, A. W., Biemans, H. J. A., \& Wopereis, I. G. J. H. (2000). "Differences Between Novice and Experienced Users in Searching Information on The World Wide Web". Journal of the American Society for Information Science, 51(6), 576-581. $\quad$ https://doi.org/doi:10.1002/(SICI)10974571(2000)51:6<576::AID-ASI9>3.0.CO;2-7

Levy, N. (2017). Nudges in a post-truth world. Department of Philosophy, Macquarie University, Sydney, New South Wales, Australia, 495-500. https://doi.org/10.1136/medethics-2017-104153

Madani, A. (2015). "Pemikiran Filsafat Al-Kindi". Lentera, IXX(2), 106-117. DOI: https://doi.org/10.21093/lj.v17i2.433.

Marwan, M. R., \& Ahyad. (2016). Anlisis penyebaran berita Hoax di Indonesia.

Mirzaqon, A., \& Purwoko, B. (2018). "Studi Kepustakaan Mengenai Landasan Teori dan Praktik Konseling Expressive Writing Library". Jurnal BK UNESA, 1, 1-8. https://jurnalmahasiswa.unesa.ac.id/index.php/jurnal-bk-unesa/article/view/22037/20201. 
Mudawamah, N. S. (2018). "Membekali Diri untuk Menghadapi Fenomena Posttruth." Nama Jurnal, 2(2), 21-28. https://doi-org

Nisrina,D., Widodo, I. A., Larassari, I. B., \& Rahmaji, F. (2020). Dampak Konsumerisme Budaya Korea (KPOP) di Kalangan Mahasiswa Fakultas Ilmu Sosial Universitas Negeri Malang. Jurnal Penelitian Humaniora. 21(1). DOI: https://doi.org/10.23917/humaniora.v21i1.8085

Ott, B. L. (2017). "The age of Twitter: Donald J. Trump and the Politics of Debasement". Critical Studies in Media Communication, 34(1), 59-68. https://doi.org/10.1080/15295036.2016.1266686

Rahmawati, R., Rusli, M., \& Yahiji, K. (2019). "Actualization of Local Wisdom in Anticipating Radicalism of Religion in Gorontalo Indonesia". Kalam, 12(2), 327-352. https://doi.org/10.24042/klm.v12i2.2676

Rusdiyanto. (2019). Pola Keberislaman Generasi Milenial Manado di Era Posttruth (pp. 95-114).

Sauda, L. (2013). Etika Jurnalistik Perspektif Al-Qur'an. Jurnal Dakwah dan Komunikasi. 7(1), 1-17. http://ejournal.iainpurwokerto.ac.id/index. php/komunika/article/download/373/337/.

Sukarman. (2019). "Rekonstruksi Peran Guru Pendidikan Islam di Era Posttruth". Jurnal PROGRESS: Wahana Kreativitas dan Intelektualitas, 7(1), 103-121. https://doi.org/10.31942/pgrs.v7i1.2726

Supriyadi, S. (2017). "Community of Practitioners: Solusi Alternatif Berbagi Pengetahuan antar Pustakawan." Lentera Pustaka: Jurnal Kajian Ilmu Perpustakaan, Informasi dan Kearsipan, 2(2), 83. https://doi.org/10.14710/lenpust.v2i2.13476

Wahyono, E., Amalia, R., \& Ranteallo, I. C. (2017). "Menelaah Lebih Dekat "Post Factual/Post truth Politics, Studi Kasus Brexit" (Analsis Resensi Media)". Nyimak (Journal of Communication), 1(1), 23-31. https://doi.org/10.31000/nyimak.v1i1.272

Wahyurudhanto. (2019). PTIK dan Dimaksudkan Sebagai Media Informasi \& Forum Pembahasan Masalah-Masalah yang Berkaitan dengan Studi Ilmu Kepolisian. Jurnal Ilmu Kepolisian. Vol 13 (1) (Vol. 13, Issue April).. https:// hetps:lidni.org. 